\title{
Idea of Money for Merchants of Gujarat in Sixteenth - Seventeenth Centuries
}

\author{
Dr. Monika Sharma (Post-Doctoral Fellow) \\ Department of History, Aligarh Muslim University, India
}

\begin{abstract}
Gujarat was the most prosperous subah in Mughal period. It enjoyed the identity of high incidence of urbanization and well developed trade and commerce. This paper intends to find out the ways and areas where these merchants invested their money. The main objective of this study would be to contextualize the idea of money for different merchants. How the various merchants invested their money to acquire political and social advantages. The items of luxury availed by the merchants and their assets outside the region.
\end{abstract}

Keywords: communities, Gujarat, trade \& commerce, merchants, money.

\section{Introduction}

An idea can be explained as a thought, a philosophy, a notion, a principal and a concept. Money has always been a medium of exchange for goods and services, whether we talk about sixteenth and seventeenth centuries. It has always played an important role in the life of human beings. Money is used as a parameter of values of goods and services on the market, and it is also a determinant of social status.

This paper intends to outline the idea of money to the merchant community and to serve this purpose the prominent merchant communities like Bohra, Bania, Parsi and Chalebi have been sampled. The intention is to assess the manner in which these merchant communities invested their capital and transformed their money in terms of luxury or productive source. How and in what manner they invested and accrued benefit of their massive wealth? What were the arenas which attracted their attention to make us estimate their various notion of money?

\section{Backdrop}

Gujarat was the most prosperous subah in Mughal period. It enjoyed the identity of high incidence of urbanization and well developed trade and commerce. The ports in Gujarat provided commodities to different places as far as south-east and west Asia. It was also a manufacturing Centre for high quality textiles which had a large demand in internal and international market. Due to its accelerated commercial activities and ports, it played an important role in the development of trade and commerce, Gujarat has always been acknowledged as commercial, urbanized and affluent region in Indian History.

\section{Idea of Money and Merchant Communities}

In sixteenth-seventeenth century, this region was the main Centre for trade and commerce and industry. Many merchants came here for business purpose and settled down in the region. M.S. Commissariat opines that the people of Gujarat must have enjoyed, on the whole, a satisfactory degree of material prosperity during the first half of the seventeenth century. Their idea of money triggered a passion for strong position in society, and maintenance of a high social status. The big merchants of different communities enjoyed a social dominance in their own community. They became representative of their community in social, religious, legal or administrative context. They also acted as communication between administrative officers and their community. The prominent merchants developed good contacts with the administrative authorities. Money played such a vital role in merchant's life and they used their money to reap more benefit which would complement powerful position.

\subsection{Bohra}

The Bohras' notion of money can be comprehended as investment in Shipbuilding industry and revel in luxuries of life like maintenance of Gardens, island and fort. The matter reached its apex in the time of Mohammad Ali.

Indian shipping flourished despite European violence. India experienced expansion of shipping in the second half of eighteenth century. As early as 1644 A.D. the numerical strength of the ships increased to considerable extent. ${ }^{1}$ For the Europeans tonnage was in terms of space while for the Indians it was for weight. M.N. Pearson mentions that during early $16^{\text {th }}$ century Muslims owned heavy ships of 375 - 800 tons capacity. ${ }^{2}$ 
There are variations among scholars estimate for the number of ships Mulla Abdul Ghafur owned. According to Manucci and Hamilton he had 20 ships. Bardolikar says he had 19 ships. Ashin Das and Pearson estimated 17 ships after the raids of Shivaji. B.G. Gokhale says that his family owned around 34 ships. In short one can acknowledge that Mulla Ghafur owned at least 17 to 34 ships. He also had a wharf ${ }^{3}$ for his shipping to the south. $^{4}$

It is difficult to estimate worthiness or durability of Indian ships. A.J. Qaiser has observed three Indian ships which were mentioned in two or three different time period in various sources, and on the basis of this time-interval, he is able to get some idea of durability or life-period of the Indian ships. ${ }^{5}$ These ships were:

$\begin{array}{llll}\text { 1. Jahaz-i-Ilahi } & - & 27 \text { Yrs. } \\ \text { 2. Salamati } & - & 42 \text { Yrs. } \\ \text { 3. Ganjawar } & - & 41 \text { Yrs. }\end{array}$

The first reference to the jahaz-i-Ilahi is in the $21^{\text {st }}$ R.Y. of Akbar $^{6}$ and the last is in the $38^{\text {th }}$ R.Y. ${ }^{7}$ Salamati was 450 tons and first noticed in 1612 A.D., next in 1622 A.D. and lastly in 1644 A.D. ${ }^{8}$ Ganjawar was first mentioned in 1619 A.D. ${ }^{9}$ and then in 1650 A.D. ${ }^{10}$

Ghafur used his financial resources as a means to make his position secure, and this became clearer at the decline of Mughal Empire, the raids by Shivaji affected Surat adversely. However the Gujaratis continued to build more ships and in these years, for the first time, they sent their vessels, admittedly only a few, to Canton and Manila. The fleet numbered well over a hundred sea going vessels of which the Mughal normally had two at sea while Ghafur controlled seventeen. ${ }^{11}$

Abdul Ghafur, who was the owner of huge property, owned a large house at saudagarpura in Surat, and a big garden in the northern suburbs of the city. He also had good relations with the administrative officers of the city. Delawar Khan, newly appointed governor of Surat who could stay anywhere, but he preferred to spend a few days in Ghafur's garden before entering the city. The maintenance of garden was an expensive affair in the sense that it involved procurement of seeds of flowers and fruits as well employing man power for its sustenance .Since they were pleasure gardens, expenditure was incurred over masonry work and its embellishment. Irrigational facilities were also arranged to match the seasonal changes.

The tradition of gardens has always been there in India, but systematic arrangement of gardens was started with arrival of Mughals in India. ${ }^{12}$ Gujarat also had a tradition of gardens since earlier times. After the invasion of this region by Mughals a mixed culture in gardens existed. ${ }^{13}$ Mandelslo witnessed 15 gardens in the area of Cambay. ${ }^{14}$ Hamilton talks about the city of Surat "the rich men of the town built many summer houses in the field and planted gardens to solace themselves and families in the pretty violent heats of April, May and June." Ashin Das Gupta also mentions some gardens owned and maintained by some wealthy merchants in Surat. $^{16}$

It is said that Ghafur had probably made his fortune in the Red Sea trade and owned one of the largest mansion in the town of Mocha. His nakhudas (ship commanders) would stay in his house during the season and sometimes for a whole year to supervise the sale of his merchandise. He was an honoured man at Mocha and enjoyed special exemptions from custom at the port. ${ }^{17}$

On the other hand, Mulla Mohammad Ali, the grandson of Ghafur, was also a big name in Surat.As Bardolikar mentioned: "મુલ્લામુહંમદચલીનોસુરતમાંસિક્કીબજતોહતો." ${ }^{\prime 8} \mathrm{He}$ was involved in local politics as well, and he interfered in the local politics." સુરતનારાજકાજમાંમાટેઉખાડપછાડમચાવતારહ્યાહતા." ${ }^{19} \mathrm{He}$ maintained a troop of about three thousand soldiers. ${ }^{20}$ "મુહંમદઅલીપાસેત્રણેકહજારસીપહીઓનુંચકબાંગીલશકર હતું." ${ }^{21} \mathrm{He}$ lived like a prince. ${ }^{22} \mathrm{He}$ invested money on luxuries and just for the sake of pomp and show and to satisfy his ambitious desires. Mohammad Ali gave up his ancestral ways due to abundance of wealth and he devoted considerable time to build an island on sea coast near the port of Gogha. He built a luxurious fort, turrets and citadel as well. He spent a large sum on it. He induced people of different places to build houses and reside there. Many people collected together to settle there. But the island was full of snakes, that is why many people died of snake-bite and rest escaped. The idea to build an island failed, and then he moved his focus to village Athawa in Surat near the bank of river Tapi, where he laid a foundation of a fort, ${ }^{23}$ with the help of port officer Bahram Khan. Mohammad Ali spent around Rs. 80,000/- for managing to obtain a sole sanad for him. He built strong fortifications. Several bazars sprang up on the road. Merchants and others resided there. Mohammad Ali also decided to unload his imported goods there. ${ }^{24}$ This was the zenith of ambitions of Mulla Mohammad Ali. 
The above instances show that Mohammad Ali was more inclined towards a life of Prince rather a merchant. His grandfather Abdul Ghafur earned a huge property but he never tried to have a troop or fort, he lived a simple life. However he had an influential personality and desired to earn more and more money. The reason behind his simplicity was his religious nature. He was associated with a mosque in the earlier phase of his life and had gone for Haj. So he did not believe in luxurious life. But Mohammad Ali had a different outlook towards life.

Another prominent Bohra Sheikh Hamid who was a merchant as well as a scholar maintained a rich library in Surat. ${ }^{25}$ Sheikh Mohammad Fazil also a great scholar, who collected thousands of rare manuscripts various countries and spent Rs. 30,00,000 for it. ${ }^{26}$

Interestingly enough Bohras believed in donation and charity. In 1751 A.D. Abdur Rehman, son of Mohmmad bin Abdur Rehman a Sunni Bohra who had a mango grove (Ambawadi) outside the Variavi gate ${ }^{27}$ in Surat and which he donated and made a trust for the maintenance of a graveyard (Qabristan) and appointed Sheikh Ahmad a trustee (mutavalli) of it. ${ }^{28}$ Bardolikar observes that Sunni Bohras' main characteristics were bravery and religious beliefs. They were active in public welfare since very early times. They were always busy in the construction of mosques, Madarsas, schools, hospitals, sarais/Inn, Vachnalayas / debate cells and libraries etc, Scholarships for poor students were common. ${ }^{29}$

\subsection{Bania}

Among the Banias, Shantidas was the court jeweler and the financer during the time of Jahangir, Shahjahan and Aurangzeb. He presented some gifts to Shahjahan at the time of his accession to the throne. ${ }^{30} \mathrm{He}$ was allowed to enter Mughal harem, which was a social privilege. According to MaganlalVakhatchand - the royal ladies considered him as their brother ${ }^{31}$ and Shah Jahan addressed him as mama or maternal uncle. ${ }^{32}$ It shows he enjoyed privileged position in the Mughal Court and this influence was because of his mercantile talent and wealth.

Shantidas also spent a big amount for religious purposes. He constructed a famous Jain Temple of Parswanath in Ahmadabad, ${ }^{33}$ and he was also involved in other religious activities. He used a big amount of his earnings on religions purposes which made him the leader or representative of his community. He secured a strong position in the Mughal court and as well as in the Jain community.

Another merchant of Surat, Virji Vora was also famous for his wealth who developed shipping insurance business along with another big name- Bhimji Parekh. ${ }^{34}$ Virji was the head of the Mahajans, and in this role he acted as the ultimate authority within this group. He was very influential and sometimes called by officials to give advice to them on commercial matters. ${ }^{35}$

Virji Vohra furnished money to Mughal princes in their need. We do not have any evidence that he ever attempted to have powerful and influential position on the basis of his money. But it is true that he was called 'merchant prince' by many historians.

One can estimate Shantidas Zaveri's wealth big amount of Rs. 5,50,000/- to Prince MuradBaksh, at the eve of war of succession by his brother. ${ }^{36}$

Makarand Mehta says that 'VirjiVohra was the first person who made coffee so popular in the region of Gujarat and often places of India., 37

Banias as a community had a different outlook towards money. B.L. Bhadani observes in his paper entitled 'Characteristics and Social Mores of the Banias', that "the Banias' favourite idea for saving money was ornaments of gold and silver. This seems to have served two purposes first, for the women social status; and second, these ornaments insured them in times of emergency.",38

Ovington says that when he visited Ahmadabad he found that Banias of the city loved to use plates of solid gold for serving different dishes to their guests at the time of any public festival or in times of jubilee, ${ }^{39}$ which indicates that it was display of their wealth and status among other fellows of their community.

Sometimes the people of this community had some secret money, which was not even in the knowledge of their family members, as the author of Ardhakathanak, Banarsidas mentioned that when his father Kharagsen came back to Jaunpur from Patna, he arranged a marriage for his eldest daughter and to bear all the 
expenses of marriage he used his secret money which he had kept underground earlier. ${ }^{40}$ It was unique feature of Banias that they used to have some secret money for their emergency and tough times.

\subsection{Parsi}

Parsis were agriculturists in the initial phases in India, but later on they grew even more ambitious. They started trade with China and Burma in $18^{\text {th }}$ century. ${ }^{41}$

Famous Parsi merchant Rustam Manekji of late $17^{\text {th }}$ century, owned a beautiful garden in Surat called Rusatam Bagh. ${ }^{42}$ The area where this garden was situated called Rustam Pura after his name:

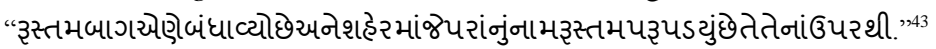

A Parsi, Banaji Limji, went to Bombay from Surat in 1690 A.D. and grew prosperous. ${ }^{44}$ In later period Parsis developed cotton trade, they exported raw cotton in large quantities and then they became owners of cotton mills. ${ }^{45}$

Jamshedji Jejeebhoy founded a 'Jejeebhoy translation found' for translating the classics of Asia and Europe into Gujarati. ${ }^{46}$

Ovington says about the Parsi community that "they have a universal kindness either in employing someone needy and able to work or in the matter of charity. We never find any beggar in their tribes and they believed in enjoying community life. ${ }^{47}$

Jejeebhoy also built fire temples (Agyaris) and towers of silence as well as bungalows for holding Parsi religious festivals. ${ }^{48}$ Two Agyaries (in Surat, one at Machhli Peeth and other was at Rustam Pura) and a Dharmashala was constructed by Fardunji Parekh of Bombay. ${ }^{49}$ In 1698 A.D., Rustam Manekji built a well in Surat for the religious purpose. ${ }^{50}$

However Malabari says about them, "They cannot understand patriotism, and though charity is the very basis of their, they are utter strangers to that greatest of divine graces. Their notions of charity is the giving away of alms, the distribution of money. Their own and anybody else's to the deserving on undeserving, with some objects, often that of earning popularity or official favoures." ${ }^{11}$

\subsection{Chalebi}

Among the Chalebis the house of Ahmad Chalebi's was the second most beautiful and big among the merchants' houses of Surat. ${ }^{52}$ Ahmad Chalebi also had a beautiful garden. ${ }^{53}$ According to Suratni Mukhtasir Haqiqat, Chalebis were also involved in shipbuilding business. Some of the Chalebi merchants owned many ships. Taahar Chalebi had 9 ships, Ahmad Chalebi had 7 ships and Saleh Chalebi was the owner of 5 ships. ${ }^{54}$ Noman Bin Hussain Chalebi had a ship named Ganjawar, and another member of his family- Usman Chalebi had many ships. ${ }^{55}$

So the mentality and idea behind the money was different from persons to person and from community to community. The main reason was to use the hard earned money, to obtain power, and to make useful strong contacts. All the merchants of different communities tried to multiply their wealth by different means.But the merchants not only used money for their own profits and interests. They also spent on charity and social service. In the accounts of European travellers, there are several references of vetenary hospitals for animals in almost all the main towns of Gujarat, which were run by money raised by merchants. ${ }^{56}$

We can conclude our discussion by acknowledging that the merchant community was by no means miserly people instead they made lavish investments in industries like shipbuilding, obtaining political privileges and social elevation by luxurious lifestyle.

\section{Money Assets Of Merchants}

\begin{tabular}{|c|c|c|c|c|}
\hline Money Investment & Bohras & Chalebis & Banias & Parsis \\
\hline 1. Ships & $\begin{array}{l}\text { Mulla Abdul Ghafur } \\
\text { (around 17-34 ships) } \\
\text { (Ghafur had control over } \\
1 / 4 \text { of entire shipping) }\end{array}$ & $\begin{array}{l}\text { TaaharChalebi (9 ships) } \\
\text { Ahmad Chalebi (7 ships) } \\
\text { SalehChalebi (5 ships) } \\
\text { Noman Bin } \\
\text { HussainChalebi } \\
\text { Usman Chalebi }\end{array}$ & $\begin{array}{l}\text { Benidas: } \\
\text { (Sea Flower } \\
\text { and Diamond) }\end{array}$ & - \\
\hline
\end{tabular}


Idea of Money for Merchants of Gujarat in Sixteenth - Seventeenth Centuries

\begin{tabular}{|c|c|c|c|c|c|}
\hline 2. & Gardens & $\begin{array}{l}\text { Mulla Abdul Ghafur } \\
\text { Abdur Rehman (mango } \\
\text { grove) }\end{array}$ & Ahmad Chalebi & - & Rustam Manekji \\
\hline 3. & Wharf & Mulla Abdul Ghafur & - & - & - \\
\hline 4. & Fort & Mulla Mohammad Ali & - & - & - \\
\hline 5. & Troop & Mulla Mohammad Ali & - & - & - \\
\hline 6. & Island & Mulla Mohammad Ali & - & - & - \\
\hline 7. & Libraries & $\begin{array}{l}\text { Sheikh Hamid } \\
\text { Sheikh Mohammad Fazil }\end{array}$ & - & - & - \\
\hline 8. & Charity & AbdurRehman & - & - & - \\
\hline 9. & Money Lending & - & - & $\begin{array}{l}\text { Shantidas } \\
\text { Zaveri } \\
\text { VirjiVora } \\
\text { Manekchand } \\
\text { Bhimji Parekh }\end{array}$ & Rustamji \\
\hline 10. & $\begin{array}{l}\text { Religious } \\
\text { Buildings }\end{array}$ & Mulla Mohammad Ali & - & ShantidasZaveri & $\begin{array}{l}\text { Jamshedji } \\
\text { Jejeebhoy } \\
\text { Fardunji Parekh } \\
\text { RustamManekji }\end{array}$ \\
\hline 11. & $\begin{array}{l}\text { Shipping } \\
\text { Insurance }\end{array}$ & - & - & $\begin{array}{l}\text { VitjiVora } \\
\text { Bhimji Parekh }\end{array}$ & - \\
\hline 12. & Coffee Trade & - & - & VirjiVora & - \\
\hline 13. & Cotton Trade & - & - & - & Banaji Limji \\
\hline 14. & Translation fund & - & - & - & $\begin{array}{l}\text { Jamshedji } \\
\text { Jejeebhoy }\end{array}$ \\
\hline
\end{tabular}

References

[1]. Fawcett,Charles, The English Factories in India, 1642-45, Clarendon Press, Oxford, 1954, p.142.

[2]. Pearson, M.N., Merchants and Rulers in Gujarat, University of California press, Barkley and Los Angeles, London, 1976, p. 8.

[3]. Wharf is the quayside area to which a ship may be moored to load and unload.

[4]. Gokhale, Balkrishna, Surat in Seventeenth Century, Bombay, 1979, p. 127.

[5]. Qaiser, A.J., 'Shipbuilding in Mughal Empire During the 17th century', I.E.S.H.R., vol. 5, 1968, pp. 164-165.

[6]. AbulFazl, Akbarnama, 3 Vols., III, Eds. H. Baveridge, Low Price Publication, Delhi, 1993 (reprint), p. 195; Ali Muhammad Khan,Mirat-i-Ahmadi, Tr. M.F. Lokhandwala, Oriental Institute, Baroda, 1965, p. 181.[

[7]. Akbarnama, III, p. 638. [

[8]. EFI, op. cit., 1642-45, p. 161.

[9]. Ibid., 1618-21, p. 113

[10]. Ibid., 1646-50, p. 324

[11]. Gupta, Ashin Das \& M.N. Pearson, India and the Indian Ocean (1500-1800 A.D.), O.U.P., New Delhi, 1987, p. 135.

[12]. Villiers, C.M., Gardens of the Great Moughals, London, 1913, p. 67; Ansari, Mohd.Azher, 'Palaces and Gardens of the Mughals, Islamic Culture, Vol. 33, 1959, p. 51

[13]. Fatma, Sadaf, 'Gardens in Mughal Gujarat”, P.I.H.C., 72nd session, Patiala, 2012, p. 441

[14]. Commissariat, M.S.,Mandelslo's Travels in Western India, Oxford, 1931, p. 42.

[15]. Hamilton, Capt. Alexander, A New Account of the East Indies (1688-1723), 2 Vols., I, London, 1739 (Reprint- New Delhi, 1995$)$, p. 145

[16]. Gupta, Ashi Das, Indian Merchants and the Decline of Surat, c.1700-1750, Manohar, New Delhi, 1994, pp. 32-33.

[17]. Gupta, Ashin Das, 'Gujarati Merchants and the Red Sea Trade', The Age of Partnership: Europeans in Asia Before Dominian, Eds. B.B. Kling and M.N. Pearson, University of Huwaii Press, 1979, p.124.

[18]. Bardolikar, Deepak, VahoraVibhutiyo, DhabakPrakashan, Vadodara, 1999, p. 18

[19]. VahoraVibhutiyo, op. cit., p.18.

[20]. Mirat-i-Ahmadi, op. cit., pp. 495-496.

[21]. VahoraVibutiyo, p.18.

[22]. Mirat-i-Ahmadi, pp. 457, 462, 495, 500

[23]. Ibid., p. 457.

[24]. Ibid., p. 462.

[25]. Desai, IshwarlalIchharam, Surat Sonani Murat, Surat, 1958, (Reprint- 2004), p. 61; Also see Bardolikar, Deepak, Sunni Vahora, BohraPrakashan, Malir City, Karachi, 1984, p. 26.

[26]. Sunni Vahora, op. cit., pp. 26-27.

[27]. Shankar, Narmada,SuratniMukhtasirHaqiqat, Union Press, Mumbai, 1866, p. 2

[28]. Sunni Vahora, p. 42.

[29]. Ibid., p. 10.

[30]. Mirat-i-Ahmadi, p. 207.

[31]. Vakhatchand, Maganlal, AmadabadnoItihas, Ahmadabad, 1977 (Reprint), pp. 25-27.

[32]. Buddhisagarji, Jain AitihasikRasmala, Eds. MohanlalDalichand Desai, 2 Vols., I, Ahmadabad, 1912, pp. 5-6.

[33]. Commissariat, M.S., A History of Gujarat, 2 Vols., II, Bombay, 1957, p. 127; Also see Commissariat, M.S., 'Imperial Mughal Farmans in Gujarat', Journals of the University of Bombay, IX (July), 1940, pp. 12, 15; Commissariat, M.S.,Mandelslo's Travels in Western India, Oxford, 1931, p. 23-24, 101-102; Thevenot, Indian Travels of Thevenot and Careri, Eds. S.N. Sen, The National Archives of India, New Delhi, 1949, pp. 13-14; Jain AitihasikRasmala, I,op.cit., pp. 8-9.

[34]. Mehta, Makarand, History of International Trade and Customs Duties in Gujarat, Baroda, 2009, p. 98.

[35]. Mehta, Makarand, Indian Merchants and Entrepreneurs in Historical Perspective, Delhi, 1991, p. 125-126.

[36]. Mirat-i-Ahmadi, p. 211; Also see 'Imperial Mughal Farmans in Gujarat', op. cit., p. 13; Commissarriat, M.S., Studies in the History of 
Gujarat, Ahmadabad, 1987, p. 16; Merchants and Rulers in Gujarat, op. cit., p. 127.

[37]. Mehta, Makarand, Gujaratna Ghadvaiya, Arunodaya Prakashan, Ahmadabad, 2007, p. 183.

[38]. Bhadani, B. L., 'Characteristics and social mores of Banias', Art and Culture, Eds. Ahsan Jan Qaisar and S.P. Verma, Jaipur, 1993, p. 51.

[39]. Ovington, J., A Voyage to Surat, Eds. H.G. Rawlingson, London, 1929 (Reprint- New Delhi, 1994), pp. 187-188.

[40]. Banarsidas, Ardhakathanak, Tr. Mukund Lath, Rajasthan PrakritBharti, Jaipur, 1981, p. 33.

[41]. Karaka, DosabhaiFramji, History of the Parsis, 2 Vols., II, London, 1884, p. 87.

[42]. SuratniMukhtasirHaqiqat, p. 7.

[43]. Ibid.

[44]. History of the Parsis, II, op. cit., p. 87.

[45]. Ibid.

[46]. Nanavutty, Piloo, TheParsis, Delhi, 1977 (Reprint-1980), p. 88.

[47]. Ovington, op. cit., p. 218.

[48]. TheParsis, op. cit., p. 88 .

[49]. SuratniMukhtasirHaqiqat, p. 7.

[50]. Ibid.

[51]. Malabari, B.M., Gujarat and Gujaratis: Picture of Men and Manners Taken from Life, W.H. Allen \& Co., London, 1882,p. 134.

[52]. Khan, Afzal, 'The Chalebi Merchants at Surat, 16th-18th centuries', P.I.H.C., 40th Session, Waltair, 1979 , p. 410.

[53]. Indian Merchants and the Decline of Surat,op. cit., p. 32

[54]. SuratniMukhtasirHaqiqat, p. 39.

[55]. Sunni Vahora, p. 28.

[56]. Valle, Pietro Della, The Travels of Pietro Della Valle in India, 2 Vols., I, Eds. Edward Grey, Haklyut Society, London, 1892, p. 70; Also see Thevenot, op. cit., p. 18; Tavernier, Jean Baptiste, Travels in India, Eds. William Crooke, 2 Vols., I, London, 1928 (ReprintNew Delhi, 1977), pp. 77-78 